\title{
ЦИФРОВЫЕ ПРАВА В СОВРЕМЕННОЙ ЮРИСПРУДЕНЦИИ
}

\section{DIGITAL RIGHTS IN MODERN JURISPRUDENCE}

V. Kolyasa
A. Zaretsky

Summary: In connection with the rapid technological progress, in the modern world there is a need to use information technology to resolve legal issues. One of the tools for regulating civil rights is digital rights, the issue of which was first raised at the legislative level in Belarus. In Russian legislation, the concept of digital rights was reduced to property rights, defining them as obligations and other rights, the content and conditions for the exercise of which are determined in accordance with the rules of the information system that meets the characteristics established by law. The use of digital rights creates a number of other problematic questions, the search for answers to which will help to streamline certain processes and relations in society.

Keywords: Internet, civil rights, digital rights, blockchain, smart contract, cryptocurrency, token, jurisprudence, law, theory of law, civil law, technology, lawyer.

\author{
Коляса Виталий Станиславович \\ Аспирант, ГАОУ ВО МГПУ \\ vit.kolyasa@mail.ru \\ Зарецкий Андрей Михайлович \\ Юрисконсульт, ПСФ «Стальконструкция» \\ Zareckiy83@gmail.com
}

Аннотация: В связи с бурным техническим прогрессом, В современном мире возникла необходимость применения информационных технологий для решения юридических вопросов. Одним из инструментов регулирования гражданских прав выступают цифровые права, вопрос о которых на законодательном уровне впервые был поднят в Белоруссии. В российском законодательстве понятие цифровых прав было сведено к имущественным правам, определяя их как обязательственные и иные права, содержание и условия осуществления которых определяются в соответствии с правилами информационной системы, отвечающей установленным законом признакам. Использование цифровых прав создает ряд других проблемных вопросов, поиск ответов на которые поможет упорядочить определенные процессы и отношения в обществе.

Ключевые слова: интернет, гражданские права, цифровые права, блокчейн, смарт-контракт, крипто-валюта, токен, юриспруденция, право, теория права, гражданское право, технологии, юрист.

Целью настоящей статьи является анализ проблемы цифрового права в российском и мировом законодательстве, так как в свете бурно осуществляемого технического прогресса и изменения общественных отношений назрела необходимость внести ясность в правовой статус понятия цифрового права.

\section{Коншепчии понимания «шифровых прав»}

До вступления Федерального закона от 18.03.2019 № 34-Ф3 «О внесении изменений в части первую, вторую и статью 1124 части третьей Гражданского кодекса (далее ГК) РФ» (далее Закон № 34-Ф3), понятие цифровых прав, как объектов гражданского права в отечественном законодательстве не существовало. Однако, до вступления указанного закона в силу, существовало несколько неофициальных концепций определения дефиниций цифровых прав. Согласно первой концепции, цифровые права - это всего лишь новый цифровой способ фиксирования прав. Сторонником указанной концепции является «Совет при Президенте РФ по кодификации и совершенствованию гражданского законодательства» [3]. Вторая концепция гласила следующее - это совокупность цифровых кодов, размещённых на материальных носителях информации. Указанное определение относило цифровые права к имущественным правам, однако законодателей не устроила данная трактовка, т.к. это был также и цифровой код [4]. Из третьей концепции следо- 
вало, что цифровыми правами признаются названные в таком качестве в законе обязательственные и иные права, содержание и условия осуществления которых определяются в соответствии с правилами информационной системы, отвечающей установленным законом признакам [5]. Именно данная концепция была закреплена в Законе № 34-Ф3, т.к. она отражала все необходимые отличительные признаки нового объекта гражданских прав.

\section{Шель закона о шифровых правах}

Изменения в Законодательстве необходимы для того, чтобы подготовить ГК РФ к принятию новых законов о криптовалюте, токенах, краудфандинге и смартконтрактах [6].

Автор данной статьи приводит следующие определения дефиниций, упомянутых в предыдущем абзаце:

Криптовалюта - вид нематериальных денежных активов, существующих в цифровом пространстве;

Токен - запись, хранящаяся в цифровом реестре информации и которая распределена в «блокчейн цепочке данных»;

Краудфандинг - способ привлечения денежных средств через сеть Интернет с целью создания или развития бизнеса, проекта и т.д. Перечисленные денежные средства:

- Можно взять в долг;

- Можно обменять на полученный процент от прибыли;

- Получить безвозмездно.

Субъектами правоотношений здесь выступают физические и юридические лица.

Смарт-контракт представляет собой компьютерный алгоритм, написанный с целью формирования, контроля и предоставления информации о владении чем-либо. Применение смарт-контракта предполагает использование технологии блокчейн, и в более узком смысле под данным понятием имеют в виду набор функций и данных (текущее состояние), находящихся по определённому адресу в блокчейне. Белоруссия стала первой страной, законодательно закрепившей смарт-контракты [8].

В Российской Федерации вопрос со смартконтрактами был урегулирован в Федеральном законе от 18марта 2019 г. №34-Ф3 «О внесении изменений в части первую, вторую и статью 1124 части третьей Гражданского кодекса Российской Федерации», который вступил в силу 1 октября 2019 г. При этом смарт-контракт рассматривается не в качестве самостоятельной сделки, а как условие об автоматическом исполнении какого-либо гражданско-правового договора. Пункт 2 статьи 309 Гражданского кодекса Российской Федерации теперь звучит следующим образом: «Условиями сделки может быть предусмотрено исполнение ее сторонами возникающих из нее обязательств при наступлении определенных обстоятельств без направленного на исполнение обязательства отдельно выраженного дополнительного волеизъявления его сторон путем применения информационных технологий, определенных условиями сделки» $[9$, С.132].

Смарт-контракт направлен на распоряжение цифровым активом, так как передача предмета сделки осуществляется в блокчейне посредством его привязки к конкретному блоку информации в этой системе. Предмет договора должен быть привязан к виртуальной единице, чтобы перевести сделку в режим смарт-контракта.

Как отмечает А. Зарецкий, трудности с правовым определением сущности смарт-контракта связаны прежде всего с отсутствием законодательного регулирования данного вопроса и неопределенными перспективами. Кроме того, некоторые условия трудно перевести на язык программирования, поэтому по этому основанию условия смарт-контракта можно поделить на программируемые и непрограммируемые. Программируемые условия - это те, которые возможно написать на языке программирования с помощью логических формул (if/ then). Непрограммируемые условия, соответственно, нельзя записать на языке программирования, например, условие о качестве товара [10].

\section{Изменения, произошедшие в Законодательстве РФ в связи с появлением шифровых прав}

До принятия Закона № 34-Ф3, в законодательстве РФ существовала существенная ошибка в перечислении объектов гражданских прав по ст. 128 ГК РФ. Она заключалась в том, что «иное имущество, в том числе безналичные денежные средства, бездокументарные ценные бумаги», выделялось из сферы имущественных прав. С принятием нового закона, указанная ошибка была исправлена и в новой редакции ст. 128 ГК РФ произошли следующие изменения: - «иное имущество, в том числе имущественные права (к которым присоединены безналичные денежные средства, бездокументарные ценные бумаги, цифровые права)». В итоге, цифровые права были отнесены к имущественным правам.

Также в ГК РФ устанавливается, что лицо сможет выразить свою волю для совершения сделки дистанционно, т.е. при помощи устройств связи. Указанные действия будут приравнены к правилам о простой письменной форме сделки. Таким образом, цифровые объекты, при использовании технологии блокчейна, могут затраги- 
вать следующий перечень прав и объектов в гражданском праве:

- услуги хостинга интернет сайтов;

- услуги по предоставлению доступа к информационным порталам;

- музыкальные произведения;

- произведения искусств;

- фотографические изображения;

- ценные бумаги;

- криптовалюта

- токены и др.

Важной особенностью перечисленных объектов будет являться их существование в цифровом виде на материальном носителе информации.

\section{Правовые риски, связанные с введением шифровых прав в Законодательство РФ}

При совершении сделок с объектами гражданского права, на которые распространяются цифровые права, возникает правовая коллизия анонимности таких сделок, т.к. указанные сделки будут проходить в сети Интернет, операции в котором можно осуществлять из любой точки планеты, где на её территории есть сотовая связь или связь через сети Интернет. В итоге, это может привести к проблемам отслеживания производимых транзакций, а также определения территории, на которой заключён договора. Кроме того, в данный момент ничто не запрещает третьему лицу, от лица одного из участников сделки, выразить его волю, что в конечном итоге может привести к нелегальному отмыванию денежных средств или корыстным нелегальным действиям при заключении соглашений.

Кроме того, использование смарт-контрактов подразумевает нарушение основных принципов права:

Сущность смарт-контракта противоречит некоторым постулатам принципа свободы договора. На основании принципа свободы договора стороны сами вправе решать заключать ли договор в форме бумажного документа или воспользоваться современными технологиями для заключения и исполнения соглашения. Однако, иногда контрагент смарт-контракта может быть неизвестен, а принцип свободы договора разрешает сторонам на свое усмотрение выбирать вторую сторону. Также, стороны могут изменять или прекращать договор по взаимному согласию, а в смарт-контракт нельзя ни внести изменения, ни прекратить исполнение ни при каком условии.

В случае нарушения прав стороной смарт-контракта такой способ защиты, как понуждение к исполнению обязательства в натуре, неприемлем, в связи с чем закономерен вопрос о соответствии смарт-контракта прин- ципу обеспечения восстановления нарушенных прав и признания смарт-контракта недействительным.

Принцип добросовестности действует только на стадии заключения смарт-контракта, пока участвуют люди, так как машина при дальнейшем исполнении полагается лишь на технические характеристики.

Смарт-контракт не способен следовать принципу защиты слабой стороны.

Таким образом, судам не стоит отрицать возможность применения основных принципов гражданского права к смарт-контактам. Необходимо аккуратно и своевременно их применять, чтобы избежать мошенничества и злоупотреблений со стороны контрагентов [9, С. 133-134].

\section{ВАияние шифровой экономики на развитие гражАанских правоотношений}

Создание искусственного интеллекта, автоматизация производства, переход на обмен данными через сеть Интернет, использование которых стало возможным благодаря использованию цифровых технологий, отрывает совершенно новые этапы развития социальных, экономических и технологических сфер общества. Однако, применение перечисленных достижений можно рассматривать двояко, т.к. с одной стороны, их использование приведёт к тому, что множество профессий устареет из-за технологического прогресса и может вызвать рост числа трудовой безработицы по причине сокращения рабочих мест на предприятиях в связи с заменой человека, как работника, на автоматизированного/ую робота/программу, расходы на которого/ую, уже на данный момент времени, является менее затратным способом экономии материальных средств организации [7]. В результате произойдёт рост числа безработных граждан, что так же, в свою очередь, приведёт к увеличению количества совершаемых правонарушений в обществе. Как итог, применение цифровых прав без существенного правового контроля для защиты гражданских и трудовых прав, может отрезвиться положительными и отрицательными достижениями.

Не стоит забывать также о возможностях применения искусственного интеллекта в юридической сфере. Например, несмотря на то, что роботы позволяют сократить время на обработку запросов, поиск нужной информации, это не означает, что они способны повлиять на исход рассматриваемого дела, для этого нужно не только доскональное знание правовой базы, но и творческие способности, которыми обладает лишь живой человек. Другим немаловажным моментом является нарушение принципа разделения труда, так как специалист в сфере информационных технологий, не имеющий юридического образования, не имеет возможности и права 
составлять юридические документы [9, С. 111].

Как показал печальный опыт Сбербанка, ошибка робота может стоить миллионных убытков, что дает основание утверждать, что искусственный интеллект не в состоянии заменить обычных банковских работников [9, C.120].

Учитывая скорость развития современной науки, вполне вероятно, что в будущем может появиться искусственный интеллект, способный заменить человека и его творческие способности, т.е. речь пойдет о машине, способной к обучению на своих собственных ошибках и опыте. Отсюда вопрос об авторских правах на новый код самообучающейся машины и на произведения, создаваемые такими роботами. В связи с тем, что цепочка создания произведения может вовлекать несколько субъектов и машин, возникают сложности в правовой квалификации. Более того, согласно статье 1259 Гражданского кодекса Российской Федерации, объектами авторских прав являются произведения науки, литературы и искусства, а также программы для ЭВМ, а согласно статье 1257 Гражданского кодекса Российской Федерации, их автором может быть признан только гражданин, творческим трудом которого это было создано. Если то, что создано человеком, охраняется законом об авторском праве и связано с понятием ноу-хау, в случае с искус- ственным интеллектом будут важны именно коммерческая ценность и принятие правообладателем разумных мер, направленных на обеспечение конфиденциальности сведений. Соответственно, созданный машиной результат может иметь признаки объекта гражданских прав, но сама машина на основании законодательства Российской Федерации не может быть признана автором. В мировой практике предлагаются различные варианты решения данного вопроса, когда правообладателями могут быть признаны программист - разработчик программы, пользователь программы, собственник оборудования, сама программа [11]. Все сводится к тому, что машина сможет стать правообладателем на результаты своей деятельности только в случае ее признания субъектом права, к чему на данный момент не готово ни общество, ни право [9, С.123].

Таким образом, возможности цифрового права, с одной стороны, упрощают процесс поиска и передачи информации и получения доступа к определенным активам посредством глобальной сети интернет. С другой - несовершенство действующего законодательства требует работы над выявленными правовыми пробелами и консолидации усилий всего мирового сообщества с целью предотвращения ухудшения социально-экономической ситуации.

\section{ЛИТЕРАТУРА}

1. Федеральный закон от 18.03.2019 N 34-Ф3 «0 внесении изменений в части первую, вторую и статью 1124 части третьей Гражданского кодекса Российской Федерации» // «Собрание законодательства РФ», 25.03.2019, N 12, ст. 1224.

2. Цифровая экономика» [Электронный ресурс] URL: https://data-economy.ru/

3. Экспертные заключения Совета при Президенте Российской Федерации по кодификации и совершенствованию гражданского законодательства 2018 г. 456 c., С. 160. [Электронный ресурс] URL: http://privlaw.ru/wp-content/uploads/2019/02/Сборник-2018-экспертные-заключения.рdf

4. М. Шестакова: Цифровые права как новый вид объектов гражданских прав. Что еще поменялось в ГК РФ // «ЭЖ-Юрист» №11 (1062) 2019 г. [Электронный ресурс] URL: https://www.eg-online.ru/article/396138/ .

5. Ст. 141.1 «Гражданского кодекса Российской Федерации (часть первая)» от 30.11.1994 N 51-Ф3 (ред. от 18.07.2019) // «Собрание законодательства РФ», 05.12.1994, N 32, ст. 3301.

6. Обзор: «С 1 октября 2019 года в ГК РФ появятся цифровые права» // Обзор подготовлен специалистами АО «Консультант Плюс».

7. Профессии, которые исчезнут до 2030 года [Электронный ресурc] URL: https://luckyea77.livejournal.com/1314822.html.

8. Смарт-контракт [Электронный ресурс] URL: https://ru.wikipedia.org/wiki/\%D0\%A1\%D0\%BC\%D0\%B0\%D1\%80\%D1\%82-\%D0\%BA\%D0\%BE\%D0\%BD\%D1\%8 2\%D1\%80\%D0\%B0\%D0\%BA\%D1\%82

9. Зарецкий А.М. Введение в юридическую профессию / А.М. Зарецкий. М.: ЭДИТУС, 2020. - 430 c.

10. C.D. Clack, V.A. Bakshi, L. Braine Smart Contract Templates: foundations, design landscape and research directions. 2016. [Электронный ресурс]URL: https://arxiv.org/pdf/1608.00771.pdf (дата обращения 27 июня 2019 г.).

11. R. Abbott I Think, Therefore I Invent: Creative Computers and the Future of Patent Law // Boston College Law Review. 2016. Vol. 57. P. 1112 - 1114.

(с Коляса Виталий Станиславович (vit.kolyasa@mail.ru), Зарецкий Андрей Михайлович (Zareckiy83@gmail.com). 